\title{
Correction to: Assessment of Exposure to Whole-Body Vibration of Dozer Operators Based on Postural Variability
}

\section{Sandeep Kumar Jeripotula ${ }^{1}$. Aruna Mangalpady ${ }^{1} \cdot$ Govinda Raj Mandela $^{1}$}

Published online: 21 January 2020

(C) Society for Mining, Metallurgy \& Exploration Inc. 2020

\section{Correction to: Mining, Metallurgy \& Exploration} https://doi.org/10.1007/s42461-020-00175-z

In the original article the author names were displayed incorrectly. They are correct here.

The online version of the original article can be found at https://doi.org/ 10.1007/s42461-020-00175-Z

$\triangle$ Sandeep Kumar Jeripotula sandeepnitk35@gmail.com

Aruna Mangalpady arunamangalpady@gmail.com

Govinda Raj Mandela mandelaraj88@gmail.com

1 Department of Mining Engineering, NITK, Surathkal, NH 66, Srinivasnagar, Surathkal, Mangalore, Karnataka 575025, India 